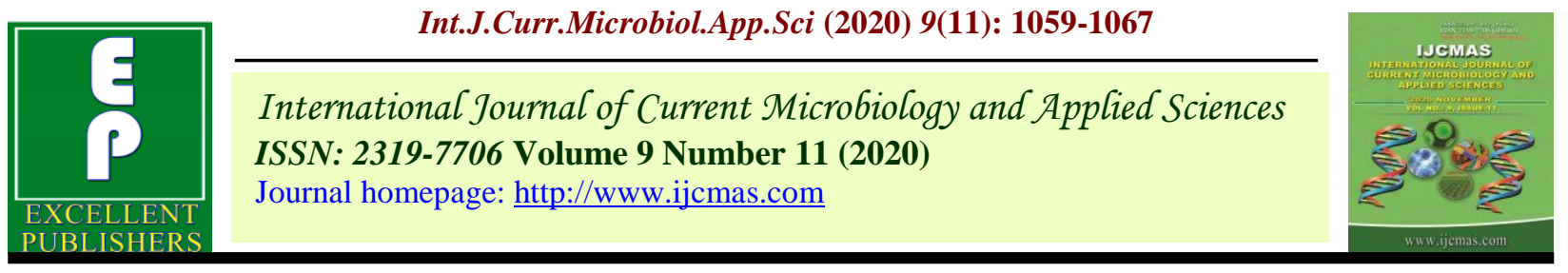

Original Research Article

https://doi.org/10.20546/ijcmas.2020.911.124

\title{
Performance of Makhana (Euryale ferox Salisb.) Genotypes under Wetland Ecosystem of North Bihar, India
}

\author{
B. R. Jana* \\ ICAR-RCER, Research Centre for Makhana, Darbhanga, Bihar, India \\ *Corresponding author
}

\begin{tabular}{|l|}
\hline Keyw or d s \\
$\begin{array}{l}\text { Makhana, } \\
\text { Genotypes, Fruit, } \\
\text { Yield, Correlation }\end{array}$ \\
\hline Article Info \\
\hline $\begin{array}{l}\text { Accepted: } \\
10 \text { October } 2020 \\
\text { Available Online: } \\
10 \text { November } 2020\end{array}$ \\
\hline
\end{tabular}

A B S T R A C T

Relative performances of ten makhana genotypes were studied at RCM, Darbhanga, during 2017-19, based on yield and morphological characters. The results revealed that the average number of fruits/plant varied from 8.22 in Manipur-9 to 13.16 in Superior Selection-1 (SS-1). The average flowering period up to 50\% decomposition was in the range of 111.67 to 140.00 days. The average number of seeds /fruit of the different genotypes varied from 68.11 in Manipur-2 to 94.37 in SS-1. After rigorous study of field harvest, it has been found that Manipur-9 recorded the average minimum field harvest of $2.0 \mathrm{t} / \mathrm{ha}$ whereas SS-1 registered the average maximum of $4.2 \mathrm{t} / \mathrm{ha}$ followed by SwarnaVaidehi (3.2 t/ha). With regard to seed character, SS-1 had the highest test weight (100 seed weight) of $96.55 \mathrm{~g}$ and had attractive rosy purple flowers and increased number of round bold seeds as compared to SwarnaVaidehi. The genotype Manipur -2 had greater number of flowers (13.37/plant) and Selection 27 had higher seed number/fruit (90.21) as compared to traditional SwarnaVaidehi variety. Hence, in the crop improvement point of view, the genotypes SS-1, SwarnaVaidehi, Selection -27 and Manipur-2 were found to be promising. The genotype SS-1 was superior over SwarnaVaidehi with regard to commercial field harvest and fresh biomass production under freshwater wetland ecosystems of north Bihar, India.

\section{Introduction}

Makhana or gorgon nut (Euryale ferox Salisb.) is a fabulous and wonderful medicinal plant from the freshwater wetland ecosystem of India. It is a very rooted but floating herb providing medicinal food, plays an important role in ecological services to rural society, nutrient recycling, and usually keeps the environment active and vibrant by fast decomposition of plant residues. The crop thrives best in stagnant water pools of freshwater ecosystems. Commercial cultivation of makhana is limited to very few states in India viz; north Bihar, Loktak Lake of Manipur, parts of West Bengal and Madhya Pradesh as well as Odisha and lower parts of Tripura and Assam (Goswami, 2003). After the release of new cultivar Swarna Vaidehi, makhana cultivation touches a new height regarding higher nut production. Makhana can be fitted in the dominant cropping system with wheat in winter under relay cropping (Mahto and Jha, 1998 and 
Singh et al., 2014). People prefer pop makhana due to low fat content, high contents of carbohydrates, protein and minerals. The calorific value of makhana raw seed and pop are $362 \mathrm{kcal} / 100 \mathrm{~g}$ and $328 \mathrm{kcal} / 100 \mathrm{~g}$, respectively. Pop makhana acquires the same rank as that of wheat, rice, other cereals and other aquatic nuts like Nelumbo and Trapa (Boyd 1968 and Jha1968). Medicinal properties of makhana have been recommended in the Indian and Chinese system of medicine 300 years ago. Makhana is recommended for treatment of diseases regarding infection of reproductive, circulatory, digestive, excretory systems. According to one school of Chinese medicine, makhana kernel is used to tonify the spleen and stops diarrhea and to strengthen the kidney. Makhana is actively used in "ChienShih" in the Chinese medicinal formula "SuShin" (a tonic especially required for the growth of the children) (Hsu and Cho, 1951). Diseases of spermatorrhoea, gonorrhoea, articular pains, micturition, and seminal loss are also treated with makhana seed kernel as food. It also influences hormonal secretion for growth and development of cells (Stuart 1911, Crevost and Petelot 1929, Roi 1955, Kariyone 1955, Das et al., 2006). The makhana is famous for its unique glucoside combinations, which protects many cardiovascular diseases (Jha et al., 1991). The farinaceous seeds have also binding action in dysentery. To overcome postnatal weaknesses in women, makhana is very important and for men and it is an aphrodisiac and has spermatogenic potential (Ho et al., 1953). In ayurveda makhana is recommended to be beneficial in Tridosas, especially in Vata (rheumatic disorders) and Pitta (bile disorders). In the Unani system of medicine, seeds are used against dysmenorrhoea. According to Quadrat et al., (2000) the seeds contain sufficient amount of vitamins B1, which can be effectively used to treat beriberi whereas its starch granules to be very small (1-3 um) as that of wild Nymphea stellata (2.2 - $7.5 \mathrm{um})$ and Trapa bipinosa Roxb. (15.91-39.0 um) which accounted for remedy for digestive disorder. Puri et al., (2000) cites the presence of important nutrients in makhana in terms of $\mathrm{Ca}, \mathrm{Mg}$ and proteins. Makhana kernel is good immunestimulant and is also used for treatment of leucorrhoea. It also regulates blood pressure, relieves numbness and aching near the waist and knees. It is suitable for arthritis, impotence and premature aging (McGuffin $e t$ al., 1997). Some makhana germplasm collected from Manipur (North East India), are also promising under the wetland ecosystem of north Bihar (Kumari et al., 2014). From B.A.U. (Bihar Agriculture University), the makhana variety Sabour Makhana-1 (BAU 2018) has been released for having better yield (3.2-3.5 t/ha) and processing quality (Pop recovery 55-60\%). According to Jana (2017), makhana cultivation with organic manures and oilcakes usually give higher nut yield (>4.0 ton/ha). Makhana is an annual, cleistogamous and photo-insensitive crop (Jana 2018a), which can be grown throughout the year and in different soil types with sufficient water (Jha and Dutta 2003). Therefore, germplasm collection and study of their performance under particular ecosystems are necessary to harness the maximum crop production and profitability. Thus, the present investigation was aimed at for screening out different genotypes of makhana with regard to their yield and quality under freshwater wetlands of North Bihar.

\section{Materials and Methods}

\section{Plant materials}

The experiment was conducted at ICARRCER, Research Centre for Makhana, Darbhanga, Bihar, during 2017-2019. The genotypes under study were Manipur-2, Manipur-4, Manipur-7, Manipur-9, Selection- 
17, Selection -23, Selection -27, Selection28, Superior Selection -1 (SS-1) and Swarna Vaidehi. The genotypes were maintained as a pure line for three (3) consecutive years and relative performances were examined along with yield.

\section{Special agronomic practices}

The field was ploughed for 2-3 times with the help of a rotavator. Weeds were completely removed. Planting distance was $1.40 \mathrm{~m} \times 1.40$ $\mathrm{m}$. About 2-3 \%, area was left for the preparation of bundh and irrigation channels. The optimum plant population was maintained around 5000/ha. The fertilizer dose of makhana was in terms of N:P:K @ 100:60:40 with 4.0-5.0 tons of FYM/ha. The crops were grown as rainy season crops with enough water, which propel the maximum growth for reproductive parts due to a conducive environment.

\section{Observations}

Morphological studies were carried out by the standard methods on plant height, no of leaves /plant, leaf diameter, no. of flowers /plant, flowering period up to $50 \%$ decomposition of plant, no. of fruits /plant, no of seeds /fruits, 100 seed weight (test weight), potential yield /plant and actual yield i.e. field harvest. Fresh biomass (kg/plant) of every genotype was taken at maturity.

\section{Statistical design}

Three years pool data were analyzed by adopting randomized block design with 3.0 replications. Data were subjected to ANOVA and mean separation were done within column $(\mathrm{p}<0.05)$ by comparing $\mathrm{CD}$. Correlation between yield and yield attributing characters of makhana plants were also studied for better explanation and understanding about potential yield.

\section{Results and Discussion}

\section{Physical characters and yield}

Relative performances of 10-makhana germplasm were studied at RCM, Darbhanga, and Bihar, India during 2017-19. The variation in vegetative and floral characters were observed in 10 types of germplasm viz; Manipur-2, Manipur-4 Manipur-7, Manipur9, Selection-17, Selection-23, Selection-27, Selection28, Superior Selection-1 and cv. Swarna Vaidehi. The genotype Manipur-2 was the relatively dwarf makhana plant (height $=100.89 \mathrm{~cm}$ ). The highest leaf diameter was found in SS-1 it was about 1.23 $\mathrm{m}$ i.e $123 \mathrm{~cm}$ (Table-1). In a different experiment Kumari et al., (2014) found that leaf area ranged from $80 \mathrm{~cm} \mathrm{X} 76 \mathrm{~cm}$ to 114 $\mathrm{cm} X 112 \mathrm{~cm}$ with the highest in germplasm number Manipur-9 (114 cmx $112 \mathrm{~cm}$ ). In our present experiment, the leaf diameter of Manipur-9 was about $0.95 \mathrm{~m}$. All the Manipur group germplasm were dwarf and they were statistically at par in respect of plant height. The genotypes Manipur-9 had less number of flowers (8.41) as compared to SS-1, which was vigorous in nature and plant height was $132.66 \mathrm{~cm}$ (Table-1). The number of leaves (16.62/plant) and flowers (15.11/plant) were found to be maximum in SS-1. The study related to evaluation of Manipur germplasm by Kumari et al., (2014) revealed that the maximum number of flowers was recorded with the germplasm number Manipur-1 (11.0). In our present study among the Manipur group of germplasm, Manipur 2 recorded to have the maximum flowering (13.37/plant). The number of leaves recorded in our present study was very high as compared to Kumari et al., (2014) and Kumar et al., (2011). This might be due to genetic and environmental effects. The number of mature fruits/plant varied from 8.22 to 13.16 and the flowering period ranged from 111.67 to 140.00 days in Manipur -9 and SS-1, 
respectively (Table-2). The results obtained by Jana (2017) and Jana (2018b) were similar to these above findings. In our present study, the number of seeds /fruit varied from 68.11 to 94.37 and 100-nut weight ranged from 81.33 to $96.55 \mathrm{~g}$ among different genotypes. The similar results were also obtained by Kumar et al., (2011). The genotype Manipur 2 had greater number of flowers (13.37/plant) and Selection 27 had higher seed number/fruit (90.21) as compared to traditional SwarnaVaidehi variety (flower/plant $=12.25$ seeds/fruit=83.22) . Regarding variation in nut weight, Jana (2017) also obtained the same results. However, peak pollination and flowering were observed between 45-90 days after transplanting. The potential yield of all the makhana genotypes were higher due to adoption of suitable agronomic practices like proper manuring, spacing and applying irrigation water. The genotype SS-1 had higher ability for potential production (6.0 t/ha) as compared to SwarnaVaidehi (4.2 ton/ha) and Selection -27 (4.2 t/ha). Furthermore, the genotypes Manipur- 9 was an early maturing variety from the Manipur group of germplasm whereas Manipur-2 had the maximum flower production (13.37/plant) within a short time (120 days from transplanting). This variety was floriferous which had desired genetic traits for breeding. However, the genotypes Manipur-9 recorded the minimum field harvest of $2.0 \mathrm{t} / \mathrm{ha}$ but SS1 registered the maximum of $4.2 \mathrm{t} / \mathrm{ha}$ (Table$2)$. This result was corroborated by the study of Kumar et al., (2011), Jana (2017) and BAU (2018). According to the BAU portal (2018) the yield of new makhana variety Sabour Makhana-1 was 3.2-3.5 t/ha. The result of the present study also revealed that the number of seeds/fruit varied from 68.11 in Manipur-2 to 94.37 in SS-1 genotypes. The genotypes Selection 27 had more harvestable yield (field harvest) as compared to SwarnaVaidehi though their potential yield was same (4.2 ton/ha each). This might be due to presence of more number of mature seeds in the former which enhanced quantity of harvested seeds. Proper manuring and irrigation are needed to get potential yield. Furthermore, final yield could be drastically reduced due to agronomic or horticultural mismanagement with short growing time and lack of manuring, spacing, proper soil type and agro-climatic condition. The genotype Manipur-9 was early maturing (117.67 days duration) promising (Table 1) genotypes that could be exploited in future breeding programmes (Table 5).

Table.1 Morphological characters of different genotypes of makhana

\begin{tabular}{|c|c|c|c|c|c|}
\hline Germplasm & $\begin{array}{c}\text { Plant height } \\
\text { (cm) }\end{array}$ & $\begin{array}{c}\text { No of leaves } \\
\text { /plant }\end{array}$ & $\begin{array}{c}\text { Leaf } \\
\text { diameter(m) }\end{array}$ & $\begin{array}{c}\text { No. of flowers } \\
\text { /plant }\end{array}$ & $\begin{array}{c}\text { Flowering up to (50 } \\
\text { \% decomposition } \\
\text { of plant) }\end{array}$ \\
\hline Manipur-2 & 100.89 & 13.67 & 1.02 & 13.37 & 120.67 \\
\hline Manipur-4 & 107.50 & 12.33 & 0.96 & 10.75 & 126.33 \\
\hline Manipur-7 & 105.99 & 11.50 & 0.85 & 9.40 & 120.33 \\
\hline Manipur-9 & 101.63 & 10.75 & 0.95 & 8.41 & 111.67 \\
\hline Selection-17 & 106.13 & 13.37 & 1.16 & 10.63 & 115.67 \\
\hline Selection-23 & 115.44 & 13.68 & 1.14 & 11.28 & 121.33 \\
\hline Selection-27 & 113.88 & 13.76 & 1.15 & 12.29 & 123.00 \\
\hline Selection-28 & 118.30 & 12.60 & 1.14 & 12.68 & 126.33 \\
\hline SS-1 & 132.66 & 16.62 & 1.23 & 15.11 & 140.00 \\
\hline SwarnaVaidehi & 115.26 & 14.11 & 1.20 & 12.25 & 126.67 \\
\hline CD at 5\% & $\mathbf{1 0 . 1 6}$ & $\mathbf{0 . 7 6 7}$ & $\mathbf{0 . 0 5 9}$ & $\mathbf{0 . 7 3 5}$ & 2.12 \\
\hline
\end{tabular}

*Flowering and vegetative growth occurs simultaneously 
Table.2 Seed and yield characters of different genotypes of makhana

\begin{tabular}{|c|c|c|c|c|c|c|}
\hline Germplasm & $\begin{array}{c}\text { No. of } \\
\text { mature } \\
\text { fruits /plant }\end{array}$ & $\begin{array}{c}\text { No of } \\
\text { seeds } \\
\text { /plant }\end{array}$ & $\begin{array}{c}\text { 100 seed } \\
\text { weight(g) }\end{array}$ & $\begin{array}{c}\text { Potential } \\
\text { Yield } \\
\text { (g)/plant }\end{array}$ & $\begin{array}{c}\text { Potenti } \\
\text { al yield } \\
\text { (t/h) }\end{array}$ & $\begin{array}{c}\text { Field } \\
\text { harvest } \\
\text { (t/h) }\end{array}$ \\
\hline Manipur-2 & 11.63 & 68.11 & 81.33 & 644.23 & 3.20 & 2.50 \\
\hline Manipur-4 & 8.95 & 76.25 & 86.33 & 589.15 & 2.90 & 2.30 \\
\hline Manipur-7 & 9.25 & 74.67 & 88.67 & 612.44 & 3.00 & 2.40 \\
\hline Manipur-9 & 8.22 & 71.92 & 85.00 & 502.51 & 2.50 & 2.00 \\
\hline Selection-17 & 8.70 & 76.45 & 93.67 & 623.01 & 3.10 & 2.50 \\
\hline Selection-23 & 10.77 & 80.42 & 89.33 & 773.71 & 3.80 & 3.00 \\
\hline Selection-27 & 10.20 & 90.21 & 92.60 & 852.05 & 4.20 & 3.30 \\
\hline Selection-28 & 9.95 & 88.27 & 90.00 & 790.46 & 3.90 & 3.00 \\
\hline SS-1 & 13.16 & 94.37 & 96.55 & 1199.06 & 6.00 & 4.20 \\
\hline $\begin{array}{c}\text { SwarnaVaide } \\
\text { hi }\end{array}$ & 10.83 & 83.22 & 93.88 & 848.28 & 4.20 & 3.20 \\
\hline CD at 5\% & $\mathbf{1 . 1 8}$ & $\mathbf{5 . 1 9}$ & $\mathbf{5 . 8 5}$ & $\mathbf{8 4 . 9 8}$ & $\mathbf{0 . 5 2 7}$ & $\mathbf{0 . 4 7 9}$ \\
\hline
\end{tabular}

$* 20-25 \%$ yield could not be obtained/lifted from field mud

$* * 4-5 \%$ immature and chaffy seeds, floating in field and decomposed faster

Table.3 Morphological characteristics and biomass production of different genotypes of makhana

\begin{tabular}{|c|c|c|c|c|c|}
\hline Germplasm & Flower color & Seed shape & $\begin{array}{c}\text { Seed coat } \\
\text { color } \\
\text { when burst }\end{array}$ & $\begin{array}{l}\text { Leaf venation } \\
\text { (mature) }\end{array}$ & $\begin{array}{c}\text { Fresh } \\
\text { biomass } \\
\text { (kg/plant) }\end{array}$ \\
\hline Manipur-2 & $\begin{array}{l}\text { Whitish } \\
\text { Purple }\end{array}$ & Round & $\begin{array}{l}\text { Whitish } \\
\text { Orange }\end{array}$ & Deep Red & 12.86 \\
\hline Manipur-4 & Purple & Round & $\begin{array}{l}\text { Whitish } \\
\text { Orange }\end{array}$ & Deep Red & 11.35 \\
\hline Manipur-7 & Purple & Round & White /butter & Light Red & 13.33 \\
\hline Manipur-9 & Purple & Round & Dull Orange & Narrow Red & 12.27 \\
\hline Selection-17 & Bluish Purple & Irregular & Dull Orange & Light Red & 15.23 \\
\hline Selection-23 & Purple & $\begin{array}{l}\text { Prominent } \\
\text { Hilum }\end{array}$ & Orange & Light Red & 18.36 \\
\hline Selection-27 & Purple & Round & Dull Orange & Light Red (LCB) & 20.94 \\
\hline Selection-28 & Purple & Irregular & Dull Orange & Deep Red & 21.87 \\
\hline SS-1 & Rosy Purple & Round & Orange to Red & $\begin{array}{l}\text { Half Deep Red } \\
\text { (LCB) }\end{array}$ & 25.32 \\
\hline SwarnaVaidehi & Purple & Round & Dull Orange & Halflight Pink (LCB) & 19.75 \\
\hline
\end{tabular}

$* \mathrm{LCB}=$ Line (venation) from center to leaf base 
Table.4 Correlation between yield and yield attributing characters of different genotypes of makhana

\begin{tabular}{|c|c|c|c|c|c|c|c|c|}
\hline $\begin{array}{c}\text { Plant } \\
\text { characters }\end{array}$ & $\begin{array}{c}\text { Plant } \\
\text { height } \\
\text { (cm) }\end{array}$ & $\begin{array}{c}\text { No of } \\
\text { leaves } \\
\text { /plant }\end{array}$ & $\begin{array}{c}\text { Leaf } \\
\text { diameter } \\
(\mathbf{m})\end{array}$ & $\begin{array}{c}\text { No. of } \\
\text { flowers } \\
\text { /plant }\end{array}$ & $\begin{array}{c}\text { Flowering up } \\
\text { to (50 \% } \\
\text { decomposition) }\end{array}$ & $\begin{array}{c}\text { No of } \\
\text { fruits } \\
\text { /plant }\end{array}$ & $\begin{array}{c}\text { No of } \\
\text { Seeds/ } \\
\text { Plant }\end{array}$ & $\begin{array}{c}\text { Test } \\
\text { weight 100 } \\
\text { seed } \mathbf{( g )}\end{array}$ \\
\hline $\begin{array}{c}\text { Potential } \\
\text { yield } \\
\text { (t/ha) }\end{array}$ & 0.944 & 0.898 & 0.752 & 0.834 & 0.872 & 0.840 & 0.862 & 0.724 \\
\hline $\begin{array}{c}\text { Potential } \\
\text { yield } \\
\text { (t/ha) }\end{array}$ & \multicolumn{7}{c}{ Positively correlated with no. of colored petals $(\mathrm{r}=0.729)$} \\
\hline
\end{tabular}

* Significant $\mathrm{r}=0.361$

Table.5 Photographs of leaf, flower and seeds (special characters) of different genotypes of makhana

\begin{tabular}{|c|c|c|}
\hline Germplasm & Special Characters & Photographs \\
\hline Manipur-2 & $\begin{array}{l}\text { No of white petals are more } \\
\text { seed coat /arils are dull } \\
\text { orange in colour }\end{array}$ & \\
\hline Manipur-4 & $\begin{array}{c}\text { Complete broad red venation } \\
\text { on upper surface of matured } \\
\text { leaf }\end{array}$ & \\
\hline Manipur -7 & Seed coat/aril colour is white & \\
\hline Manipur-9 & $\begin{array}{c}\text { Complete narrow red } \\
\text { venation on upper surface of } \\
\text { matured leaf }\end{array}$ & \\
\hline Selection-17 & $\begin{array}{l}\text { Bluish purple elongated } \\
\text { flower petals. No of petals } \\
\text { are less. }\end{array}$ & \\
\hline
\end{tabular}




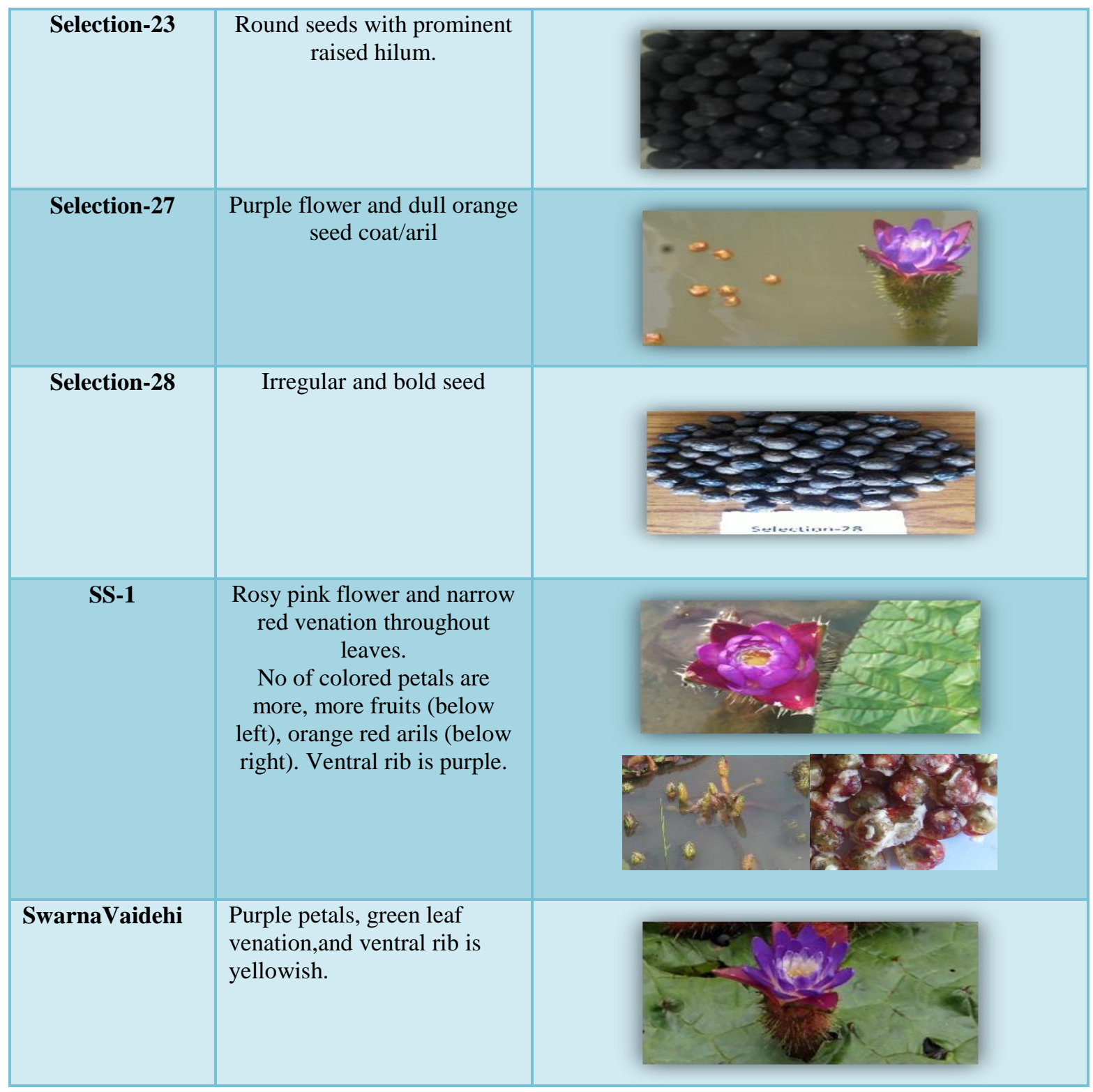

\section{Morphological characters}

SS-1 had rosy purple flowers with very narrow red venation in matured leaves from the center of the leaf to its base. Seeds were bold round shaped and possessed the maximum biomass production $(25.32$ $\mathrm{kg} /$ plant) followed by Selection -28 (21.87kg/plant) (Table-3) which were almost double as reported by Kumari et al., (2014). This might be due to genetic characters of these high yielding varieties and long growing condition in the present study. Jana (2017) also supported the findings of these above results where biomass production was 21.91 $\mathrm{kg} / \mathrm{plant}$ under organic cultivation. SwarnaVaidehi, which had purple flowers with green upper surface of the leaf and very short light pink venation from center of the leaf to its base. In respect of leaf character, the prime difference between SS-1 and SwarnaVaidehi due to colour of ventral rib, which was purple for the former and yellowish for the later. The genotype Selection-17 had bluish purple petals and numbers were less. Jana (2018a) also obtained 
the similar results. The leaves of the genotype Selection 27 had light red venation, bold round seeds and dull orange seed coats/arils. All the Manipur germplasm were edible for their floral and fruit parts. The seeds were medium to small. The genotype Manipur-9 possessed the lowest biomass production though it was medium in stature. This might be due to very light in weight of all plant parts i.e. in the texture with respect to leaves, flowers, and vegetative stems. The flower of the genotype Manipur-2 had more white petals as compared to red ones with dull orange seed coats/arils (Table-3). The genotype Selection -28 had irregular bold seeds and dull orange seed coat/aril (Table$3 \& 4)$.

\section{Correlation study}

Potential yield of makhana crop was positively correlated with plant height $(\mathrm{r}=0.944)$, no of leaves /plant, $(\mathrm{r}=0.898)$, leaf diameter $(\mathrm{r}=0.752)$, no. of flowers /plant $(\mathrm{r}=0.834)$, flowering up to $(50 \%$ decomposition) ( $\mathrm{r}=0.872)$, no of fruits /plant $(\mathrm{r}=0.840)$, no of seeds/fruit $(\mathrm{r}=0.862)$ and test weight of 100 seed $(r=0.724)$. From the calculation of no. of colored petals, it was found that yield (t/ha) was positively correlated with more number of attractive colored petals $(r=0.729)$ present in a flower (Table-4).

In conclusions the makhana genotypes viz; SS-1, SwarnaVaidehi and Selection -27 were found to be promising for nut yield i.e. production and pop making whereas Manipur2 may be consumed as vegetable for having of their soft fruit and edible flower and fruit stalks.

\section{Conflict of Interests}

Author declares that there is no conflict of interest.

\section{References}

B.A.U. Portal. 2018. Research https://www.bausabour.ac.in/varietiesdeveloped.aspx

Boyd, C.E. 1968. Fresh water plants: a potential source of protein. Economic Botany. 23: 123-27.

Crevost, C. and Petelot, A. 1929. Catalogue des produitsdel Indochina. Plant Medicinales. Ann. Chim. (Rome), 32:122.

Das, S., Der, P., Roychoudhury, U., Maulik, N. and Das, D.K. 2006. The effect of Euryale ferox Makhana an herb of aquatic origin, on myocardial ischemic reperfusion injury. Mol. Cell Biochem., 289 (1-2): 55-63.

Gopalan, C., Sastri, R., Balasubramanian, S.C. 1998. Nutritive value of Indian foods, National Institute of Nutrition, 1998, ICMR, Hyderabad. India.

Goswami, M.M. 2003. Ecology of Euryale feroxSalisb. In flood plan wetlands of Assam. In: Makhana (eds) by Mitra R.K., Jha V. and Dehadrai, P.V., ICAR, New Delhi, India.

Ho, H., Cheu, Y. and Luo, I.1953. The detection of vitamin $\mathrm{B}$, and $\mathrm{C}$ in Chinese drugs. J. Taiwan Pharm. Assoc., 5: 5-20.

Hsu, H. and Cho, C. 1951. The nutritive value of Chinese formula "su-shin". $J$. of Taiwan Pharm. Assoc., 3: 25-28.

Jana, B.R. 2017. Organic cultivation of makhana in low land during rainy season for enhancing farm profitability. Int. J. Ecosystem and Ecology Sci., 7(3): 419-424.

Jana, B.R. 2018. Flower characteristics and pollination behavior of Euryale ferox Salisb. American Journal of Plant Sciences. Flowers and Pollen 9(4): pp 722-731.

Jana, B.R., Srivastava, Anuradha and Idris, Md. 2018. Climate Change Effects and 
Quality Makhana Production under Wetland Ecosytem of North Bihar. Int. J. Curr. Microbiol. App. Sci., 7(12):578-587.

Jha, S.N. and Dutta, R.N. 2003. Soil chemistry ofmakhana (Euryale ferox Salisb.) cultivation. In: Makhana(eds) by Mitra R.K., Jha V. and Dehadrai, P.V., ICAR, New Delhi, India.

Jha, U.N. 1968. The pond ecosystem. Ph.D. thesis submitted to Banaras Hindu University, Varanasi, India,

Jha, V., Barat, G.K. and Jha, U.N. 1991. A Nutritional evaluation of Euryale feroxSalisb (Makhana). J. Food Sci .and Tech., 8 (5): 326-28.

Kariyone, T. and Kimura, Y. 1949. JapaneseChinese Medicinal Plants. Their constituents and Medicinal uses, 2nd edition. 519.

Kumari, A., Singh I.S., KumarLokendra., Kumar, A., Kumar, R. and Gupta V.K. 2014. Morphological Characteristics of Makhana Germplasm of Manipur under Darbhanga Conditions. $J$. AgriSearch,1(3): 157-160.

Mahto, A and Jha, V. 1998. Maximizing productivity in the low-lying field of Darbhanga (North Bihar) India: A case study of crop rotation between makhana (Euryale feroxSalisb.) and wheat (Triticum aestivum Linn.). J. Freshwater Biol., 10 (1-2): 25-31.

McGuffin, M., Hobbs, C. and Upton. R. (1997) (eds.) American Herbal Products Association's, Botanical Safety Handbook. Boca Raton, FL: CRC Press, 199.

Puri, A. , Sahai, R. and Singh K.L. 2000. Immuno-stimulant activity of dry fruits and plants materials used in Indian traditional medical system for mothers after child birth and invalids. J. Ethnopharmacology. 71 (1-2):89-92.

Qudrat, I., Khuda, M., Mukherji, B.D. Hossain, M.A. and Khan, N. A. 2000. Properties of certain starch varieties and their sources in East Pakistan. Pak. J. Scientific and Industrial Res., 3: $159-162$.

Roi, J. 1955. Traite des plantes Medicinales chinoises, Paris. 125.

Singh, I.S., Lokendra, Kumar., Singh, A.K., Bhatt, B.P. And Singh, S.P. 2014. Impact of makhana (Euryale feroxSalisb) based cropping system on nutrient dynamics of Inceptisols of North Bihar. Int. J. Agricult. Stat. Sci. 10(1):125-129.

Stuart, G.A. 1911. Chinese Materia Medica. Vegetable Kingdom, 163.

\section{How to cite this article:}

Jana, B. R. 2020. Performance of Makhana (Euryale ferox Salisb.) Genotypes under Wetland Ecosystem of North Bihar, India. Int.J.Curr.Microbiol.App.Sci. 9(11): 1059-1067. doi: https://doi.org/10.20546/ijcmas.2020.911.124 